\title{
SOLAR SUPPORTED STEAM PRODUCTION FOR POWER GENERATION IN LIBYA
}

\author{
${\text { Monaem Elmnifi }{ }^{*} \text {, Moneer Amhamed }}^{2}$, Naji Abdelwanis ${ }^{3}$, Otman Imrayed ${ }^{4}$ \\ ${ }^{1}$ Joife Company of oil technology, Benghazi, Libya \\ ${ }^{2}$ Electrecity Company, Elmarj, Libya \\ ${ }^{3}$ Department of Mechanical Engineering, Omar Al-Mukhtar University, Libya \\ ${ }^{4}$ Department of Electrical \& Electronics Engineering, Sirte University, Libya \\ *Corresponding Author Email: monm.hamad@yahoo.co.uk
}

This is an open access article distributed under the Creative Commons Attribution License, which permits unrestricted use, distribution, and reproduction in any medium, provided the original work is properly cited

\section{ARTICLE DETAILS}

\section{Article History:}

Received 12 November 2017 Accepted 12 December 2017 Available online 1 January 2018

\section{ABSTRACT}

A hybrid power plant including a solar central receiver for receiving solar radiation and converting it to thermal energy. The power plant includes a molten salt heat transfer medium for transferring the thermal energy to heat exchanger. The use of fossil fuels should be reduced in near future due to their limited resources and increasing ecological impacts. Therefore, increased interest and incentives have been created for development of electricity supply utilizing renewable energy such solar energy, which has long-range potential and is applicable in most geographical regions Libya is located in the center of North Africa. The vast majority of the country is located in the Sahara Desert, which is characterized by its high potential for solar energy. This study provides an evaluation study for the solar power plant with a capacity equal to $70 \mathrm{GW} /$ year to support generating electricity. The System Advisor Model (SAM) model system, developed by the National Office of Renewable Energy (NRE), was used to assess the plant's active and economic performance.

\section{KEYWORDS}

Solar, Direct Steam Generation, Parabolic trough, Hybrid systems

\section{INTRODUCTION}

AS well known the main resources of energy in Libya are oil and gas which results in high emission of carbon dioxide and other gases. As the modern world consistently emphasizes on using renewable energy to generate electricity, which is harmless to the environment. Hybrid power plant is a new developed technology that is used to convert solar energy with any system that generates energy $[1,2]$.

Parabolic trough solar power plants are the most proven system of concentrating solar power (CSP) techniques [3-5]. There are nine parabolic trough solar electricity generating system (SEGS) in California, USA illustrates the capability of this technology to be a reliable, renewable energy resource. This system has been operating commercially as largescale thermal solar power plants with a total output of $345 \mathrm{MW}$ [4]. CSP plants are promising technologies to be the alternative clean energy resource to meet the increasing energy demand and thus reduce the environmental impact. It is predicted that CSP will play a significant role in providing the energy to meet the world's energy demands which are increasing rapidly in response to the growing economics in both developed and developing countries. Electricity produced by CSP in the Mediterranean and North African (MENA) region can be used to improve the local energy production systems and can be exported to the EU. It aims at interconnecting the electricity grids of the Mediterranean, North Africa regions Europe, generating power by employing CSP in MENA and exporting it to the EU using a high voltage direct current HVDC network. The goal is to export about $700 \mathrm{TWh} /$ year to the EU by 2020 . The anticipated cost is $6 € / \mathrm{kWh}[6,7]$.

Parabolic trough power plants can be operated in different configurations and operating systems. They can be operated in only solar mode where the solar collector's array is the only energy resource for the thermal cycle [8]. Alternatively, they can be operated as a hybrid system, where a backup fossil fuel boiler is used in parallel to the solar collector's array [9]. Most of the existing trough plants use synthetic oils as a heat transfer medium to supply the heat gained by the solar collectors to a Ranking cycle. However, a new concept of direct steam generating (DSG) has been introduced, where the water is evaporated and superheated in the solar collector tubes directly. This operation technique results in a cost reduction of up to $26 \%$ and thermal efficiency improvement [10]. The equivalent solar thermal power station is one of the most attractive technologies to produce electricity from solar thermal energy. This paper presents an assessment study of the solar power plant for supported electricity generation. This solar energy parabolic plant of $70 \mathrm{GW} /$ year output is suggested by this study. Taking into account the proposed location of this plant in the northern regions if applied.

\section{CONCENTRATING SOLAR POWER (CSP) PLANTS}

CSP plants provide energy with high temperatures which is used to run conventional power cycles such as the steam turbine, gas turbine and Sterling engine. Although CSP plants are used mostly for electricity generation, they can, however, be used in many industrial applications. Different applications for CSP systems. One of the most important boundaries for choosing the most suitable technique for any proposed application is the operating temperature. For example, in applications when the desired operating temperature is above $600{ }^{\circ} \mathrm{C}$, the suitable technique is the central solar tower.

\section{- $\quad$ Solar tower system}

- Parabolic dish-engine

- $\quad$ Liner Fresnel system

\section{- Parabolic trough system}

Parabolic trough system uses a parabolic shaped reflector. The concentration ratio can be 80 or more [11]. The collected energy then absorbed by heat transfer fluid runs inside the absorbed tube parabolic trough technology supplies energy at a temperature of up to $400{ }^{\circ} \mathrm{C}$. This energy is supplied to run either a simple Rankin cycle or hybrid system. The heat transfer fluid which is used to absorb the heat can be either water or synthetic oils. Figure 1 shows the parabolic trough system elements. The parabolic trough is the 
most proven technology in solar thermal power plant applications thanks to the nine SEGS in the California desert, USA. They have been running commercially for more than 20 years as large-scale electric power plants. They are supplying 354 MWe to the southern Californian grid and have shown that there is no doubt about the technology's reliability and its potential to be a competitive energy resource. Most of the commercially proposed solar thermal power plants are planned to be operated based on the parabolic trough system $[10,12,13]$.

Table 1: Performance data of various CSP technologies [14]

\begin{tabular}{|c|c|c|c|c|c|c|c|}
\hline & $\begin{array}{c}\text { Capacit } \\
\text { y } \\
\text { Unit } \\
\text { MW }\end{array}$ & $\begin{array}{c}\text { Conce } \\
\text { ntrati } \\
\text { on }\end{array}$ & $\begin{array}{c}\text { Peak } \\
\text { Solar } \\
\text { Efficienc } \\
\mathbf{y} \\
\end{array}$ & $\begin{array}{c}\text { Annual } \\
\text { Solar } \\
\text { Efficienc } \\
\mathbf{y}\end{array}$ & $\begin{array}{c}\text { Thermal } \\
\text { Cycle } \\
\text { Efficienc } \\
y\end{array}$ & $\begin{array}{c}\text { Capacity } \\
\text { Factor } \\
\text { (solar) }\end{array}$ & $\begin{array}{c}\text { Land } \\
\text { Use } \\
\mathbf{m}^{2} / \mathbf{M} \\
\text { Wh/y }\end{array}$ \\
\hline \multirow[t]{2}{*}{ Trough } & $10-200$ & $80-70$ & $21 \% d$ & $\begin{array}{c}10-15 \% \\
\mathrm{~d}\end{array}$ & $\begin{array}{c}30-40 \% \\
\text { ST }\end{array}$ & $24 \% d$ & $6-8$ \\
\hline & & & & $\begin{array}{c}17-18 \% \\
(\mathrm{p})\end{array}$ & & $\begin{array}{c}25-90 \% \\
\text { (p) }\end{array}$ & \\
\hline Fresnel & $10-200$ & $\begin{array}{l}25- \\
100\end{array}$ & $20 \%$ (p) & $\begin{array}{c}9-11 \% \\
\text { (p) }\end{array}$ & $\begin{array}{c}30-40 \% \\
\text { ST }\end{array}$ & $\begin{array}{c}25-90 \% \\
\text { (p) }\end{array}$ & $4-6$ \\
\hline \multirow[t]{2}{*}{$\begin{array}{l}\text { Power } \\
\text { tower }\end{array}$} & $10-150$ & $\begin{array}{l}300- \\
1000\end{array}$ & $20 \%$ (d) & $\begin{array}{c}8-10 \% \\
\text { (d) }\end{array}$ & $\begin{array}{c}30-40 \\
\% \text { ST }\end{array}$ & $\begin{array}{c}25-90 \% \\
\text { (p) }\end{array}$ & $8-12$ \\
\hline & & & $35 \%$ (p) & $\begin{array}{c}15-25 \% \\
\text { (p) }\end{array}$ & $\begin{array}{c}45-55 \\
\% \text { CC }\end{array}$ & & \\
\hline \multirow[t]{2}{*}{$\begin{array}{l}\text { Dish- } \\
\text { sterling }\end{array}$} & $0.01-0.4$ & $\begin{array}{l}1000- \\
3000\end{array}$ & $29 \%$ (d) & $\begin{array}{c}16-18 \% \\
\text { (d) }\end{array}$ & $\begin{array}{l}30-40 \\
\% \text { Stirl. }\end{array}$ & $25 \%$ (p) & $8-12$ \\
\hline & & & & $\begin{array}{c}18-23 \% \\
\text { (p) }\end{array}$ & $\begin{array}{c}20-30 \\
\% \text { GT }\end{array}$ & & \\
\hline
\end{tabular}

$\mathrm{d}=$ demonstrated, $\mathrm{p}=$ projected

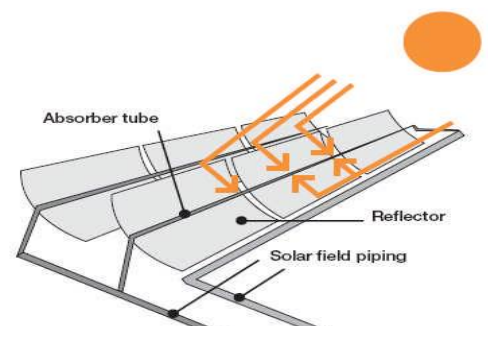

Figure 1: Parabolic trough system [13]

\subsection{Parabolic trough}

This technology is an appropriate technology to be used with the ISCC cycle. The world's largest commercial solar thermal power plants are based on parabolic trough technology. The world's largest nine commercial largescale thermal solar power plants are outlined in Appendix C. The parabolic trough advantages over the other CSP technologies are shown in Appendix B. Trough systems are the only ones proven in the field as large-scale commercial units. Table 1 shows a comparison between the different CSP performances. The reasons for choosing parabolic trough technology to be used in this research are summarized in as:

- Proven commercially in the field for more than 20 years.

- $\quad$ Accepted technology by the World Bank.

- $\quad$ Reliable systems.

- $\quad$ Can be installed in large capacity units, i.e. 50 to $200 \mathrm{MW}$

\section{HYBRID SYSTEMS}

The hybrid system solar power generation concept uses a backup fossil fuel boiler which is used in parallel to the solar field to guarantee reliable operation at night-time or when no solar radiation is available. Many configurations have been introduced as hybrid systems. One fossil fuel boiler or more is used to supply the required energy for the thermal cycle. Boilers can be used to superheat the steam in the thermal cycle. Moreover, in the hybrid systems one solar field or more is allocated in different positions either to heat the feed water or superheat the steam [15]. Figure 2 shows hybrid trough solar power plant.

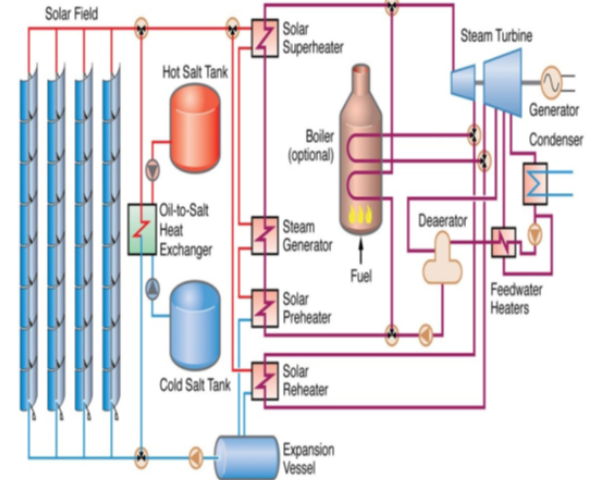

Figure 2: Solar trough system with fossil fuel backup [13]

\section{THE CURRENT SITUATION OF THE LIBYAN ELECTRICITY GENERATION}

Libya is an oil producing country located in North Africa. Its area is $1,750,000 \mathrm{~km} 2$ and most of this land is a desert. The majority of its population (6 million) lives on the coast. Libya receives daily high amounts of solar radiation with a daily average on a horizontal surface of 8.1 $\mathrm{kWh} / \mathrm{m} 2 /$ day. Solar radiation duration average in Libya is about 3500 hours/year [16]. The only electricity supplier in Libya is the General Electricity Company of Libya (GECOL) which is a nationalized company.

The electricity demand is growing rapidly ( $9 \%$ in 2010) due to economic growth and improving Lifestyle. GECOL has installed a number of power plants since it was established in 1984 [17]. Figure 3 shows the installed power plants in Libya. The power sector in Libya currently relies on gas turbine and steam turbine power plants to produce the required electricity. In previous years some small diesel power plants used to contribute to the energy supply, especially in remote regions. Thanks to the improvement in the network of electricity supply, diesel power plants are no longer used. Table 2, Table 3 , Table 4 shows the operating power plants which supply electricity to the Libyan grid.

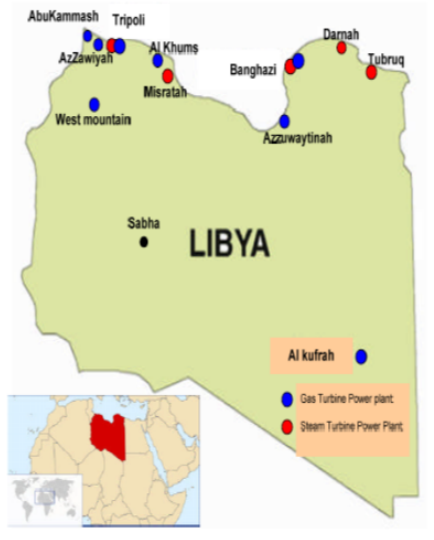

Figure 3: Installed power plants

Libyan power generation analysis shows that about $60 \%$ of the electricity generation is being generating by gas turbine units [17]. That means that gas turbine units are being used to cover a large portion of the base load. Figure 4.2 shows the Libyan electricity generation system by type. The maximum and minimum loads are shown in table 5 for year 2010. The maximum load was $5759 \mathrm{MW}$ and the minimum load was $2103 \mathrm{MW}$.

Table 2: Libyan power plants capacity (GECOL, 2010) Steam Turbines

\begin{tabular}{|c|c|c|c|c|c|}
\hline Plant & Fuel Type & $\begin{array}{c}\text { Units } \\
\text { No. }\end{array}$ & $\begin{array}{c}\text { Unit } \\
\text { Capacit } \\
\text { y MW }\end{array}$ & $\begin{array}{c}\text { Plant } \\
\text { Capacity } \\
\text { MW }\end{array}$ & $\begin{array}{c}\text { Current } \\
\text { available }\end{array}$ \\
\hline Al Khums & Heavy/Gas & 4 & 120 & 480 & 300 \\
\hline West Tripoli & $\begin{array}{c}\text { Heavy } \\
\text { Heavy }\end{array}$ & $\begin{array}{c}4 \\
2\end{array}$ & $\begin{array}{c}65 \\
120\end{array}$ & $\begin{array}{c}260 \\
240\end{array}$ & $\begin{array}{c}70 \\
100\end{array}$ \\
\hline Misratah & Heavy/Gas & 6 & 84.5 & 507 & 180 \\
\hline Darnah & Heavy & 2 & 65 & 130 & 40 \\
\hline Tubruq & Heavy & 2 & 65 & 130 & 80 \\
\hline $\begin{array}{c}\text { Total } \\
\text { generation }\end{array}$ & & 20 & 519.5 & 1747 & 770 \\
\hline
\end{tabular}


Table 3: Libyan power plants capacity (GECOL, 2010) Gas Turbines

\begin{tabular}{|c|c|c|c|c|c|}
\hline Abukammash & Light & 3 & 15 & 45 & 17 \\
\hline Al Khums & Light/gas & 4 & 150 & 600 & 500 \\
\hline South Tripoli & Light/gas & 5 & 100 & 500 & 400 \\
\hline North Bangazi & Light/gas & 2 & 285 & 570 & 500 \\
\hline Azzuwaytinah & Light/gas & 4 & 50 & 200 & 120 \\
\hline Al kufrah & Light & 2 & 25 & 50 & \\
\hline Misratah & Light/gas & 2 & 285 & 570 & 500 \\
\hline West Mountain & Light/gas & 1 & 156 & 156 & 140 \\
\hline sarir & Light/gas & 1 & 285 & 285 & 560 \\
\hline Total generation & & 28 & 1507 & 3600 & 2987 \\
\hline
\end{tabular}

Table 4: Libyan power plants capacity (GECOL, 2010) Combined cycle plants

\begin{tabular}{|c|c|c|c|c|c|}
\hline & Gas.Light & 4 & 165 & 660 & 600 \\
Azzawiyha & $\begin{array}{c}\text { Gas } \\
\text { steam. Without } \\
\text { fuel }\end{array}$ & 3 & 165 & 330 & 300 \\
& 2 & 450 & 375 \\
\hline North Bangazi & $\begin{array}{c}\text { Gas.Light/gas } \\
\text { Gas } \\
\text { steam. Without } \\
\text { fuel }\end{array}$ & 3 & 150 & 450 & 390 \\
1 & 2 & 150 & 300 & 250 \\
\hline Total generation & & 15 & 945 & 2355 & 2055 \\
\hline $\begin{array}{c}\text { Total public } \\
\text { generation }\end{array}$ & & 63 & 2971.5 & 7702 & 5812 \\
\hline
\end{tabular}

Table 5: The maximum and minimum load (2010) (GECOL, 2010)

\begin{tabular}{|c|c|c|c|}
\hline Month & $\begin{array}{r}\text { Min } \\
\text { load MW }\end{array}$ & Peak load MW & Min/Max load \\
\hline January & 2325 & 5360 & 0.43 \\
\hline February & 2268 & 4310 & 0.52 \\
\hline March & 2201 & 4920 & 0.44 \\
\hline April & 3103 & 5523 & 0.56 \\
\hline May & 3765 & 5759 & 0.65 \\
\hline June & 3275 & 5435 & 0.60 \\
\hline July & 2750 & 5285 & 0.52 \\
\hline August & 2325 & 4505 & 0.51 \\
\hline September & 2103 & 4260 & 0.49 \\
\hline October & 2343 & 4505 & 0.52 \\
\hline November & 2312 & 4880 & 0.47 \\
\hline December & 2496 & 4965 & 0.50 \\
\hline
\end{tabular}

It is obvious that there is a big different between the peak loads and the minimum loads. The minimum load to the maximum load ratio varied from $43 \%$ to $65 \%$ in 2010 . Due to this big difference the electricity supplier installed a large capacity to supply electricity for peak periods. So that was the reason for this large portion of gas turbine electricity generation. Because of the gas turbines are suitable for peak demand, where they can be easily and quickly connected to grid.

\section{METHODOLOGY OF THE STUDY}

Libya lies in the center of North Africa between latitudes $20-39^{\circ} \mathrm{N}$ and longitude $10-25^{\circ} \mathrm{E}$. The country is located in the Sun Earth belt and about $88 \%$ of its territory is considered in the desert. According to the report of the Institute of Thermodynamics Engineering at the German Space Center in Stuttgart [18]. Which shows that direct natural solar radiation varies from $1900 \mathrm{kWh} / \mathrm{m} 2$ / year in the far north of the country to more than $2,800 \mathrm{kWh} / \mathrm{m} 2$ /year in parts of the south-east. Concentrated solar power plants can be considered economically valuable only for sites with direct solar radiation above $1800 \mathrm{kWh} / \mathrm{m} 2$ / year [19]. All Libyan lands can meet this condition with higher potential than the southern parts of the country. Prior to the evaluation study, it is proposed to operate a $70 \mathrm{GW} /$ year for operation in typical climate conditions the case of northern Libya. The design parameters for this plant are summarized in Table 6. Universities of solar energy are directed north and south the parallel direction of the horizontal plan. This plant uses the VP-1 Therminol as heat transfer fluids.
Table 6: Design parameters of the proposed parabolic trough power plant

\begin{tabular}{|c|c|}
\hline Characteristics & Value \\
\hline $\begin{array}{c}\text { Total plant } \\
\text { capacity }\end{array}$ & 20 MWe \\
\hline $\begin{array}{c}\text { Total land } \\
\text { area }\end{array}$ & 61 acres \\
\hline Condenser type & Air-cooled \\
\hline $\begin{array}{c}\text { Number of } \\
\text { loops }\end{array}$ & 17 \\
\hline Single loop aperture & $5248 \mathrm{~m}^{2}$ \\
\hline Solar multiple & 2 \\
\hline Number of washes per year & 63 \\
\hline Rated cycle conversion efficiency & $35 \%$ \\
\hline Water usage per wash & $0.7 \mathrm{~L} / \mathrm{m}^{2}$ aperture \\
\hline Row spacing & $15 \mathrm{~m}$ \\
\hline Number of field & 2 \\
\hline Receiver type & Schott ptr80 \\
\hline Absorber tube inner diameter & $0.076 \mathrm{~m}$ \\
\hline Absorber tube out diameter & $0.08 \mathrm{~m}$ \\
\hline Absorber material type & $304 \mathrm{~L}$ \\
\hline HTF type & Vp -1 \\
\hline Design loop outlet temperature & $293 c^{\circ}$ \\
\hline Design loop inlet temperature & $391 c^{\circ}$ \\
\hline Full load hours & $6 \mathrm{~h}$ \\
\hline Storage type & Tow tank \\
\hline Storage fluid & Hitec solar salt \\
\hline Tank diameter & $17.0369 \mathrm{~m}$ \\
\hline Tank height & $20 \mathrm{~m}$ \\
\hline
\end{tabular}

As explained earlier in this paper, the critical criteria for determining the feasibility of establishing a site for the application of concentrated solar technology is the annual state of the weather. One site was selected for this study to represent the climatic conditions of the northern coast of Libya due to the intensity of solar radiation in these areas. at $32.19^{\circ}$ longitudes north and 20.15 ${ }^{\circ}$ latitude east. The average monthly energy and load is demonstrated in Figure 4. The overall mean temperature is about $21.7 \mathrm{C}^{-}$ and the overall mean wind speed is $3.4 \mathrm{~m} / \mathrm{s}$. The analysis of performance and economic feasibility of the (SAM) software 2017 [22]. SAM was developed by National Renewable Energy Laboratory (NREL) and has the capability to simulate different renewable energy systems including parabolic trough power technology. In addition, it can make cost estimation based on installation and operating costs. More specifically, SAM uses the well-known package TRNSYS as transient simulation code [20-23].

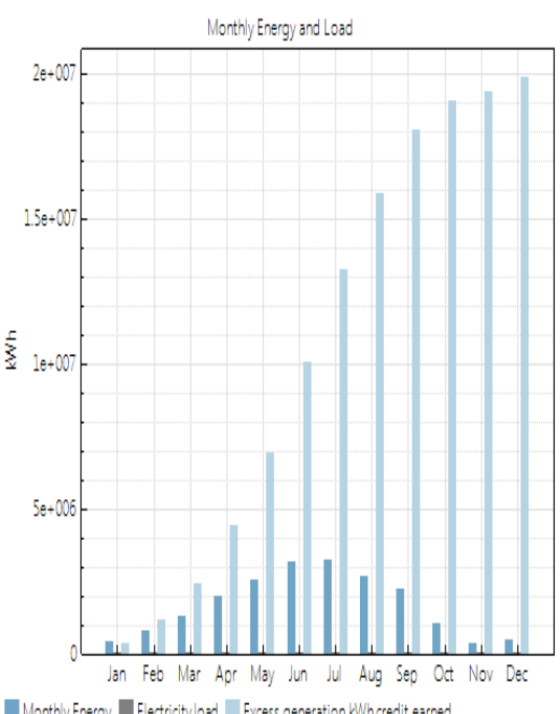

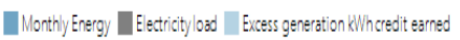




\section{OPTIMIZATION OF SOLAR MULTIPLE}

One of the most important criteria that have a significant impact on the cost of energy production is the multiplicity of solar energy extinguishing Levelized Cost of Energy LCOE of electricity produced by the concentrated solar system. Solar multiplicity can be defined as the ratio of the actual solar field to the minimum size required to operate the power block at full capacity under normal irradiation conditions. The increase in multiple solar energy, combined with thermal energy storage, can increase the power of the block which reduces the LCOE of the entire plant.

However, increasing solar energy is also multiple increases the tribal cost of the system. This paradoxical effect of this parameter needs to be optimized for multiple solar identification. The simulation results of the optimization process is shown in Figure 5. The LCOE is decreasing from $8.78 \mathrm{c} \$ / \mathrm{kWh}$ at solar multiple until it reaches the minimum value of 6 $\mathrm{c} \$ / \mathrm{kWh}$ with solar multiple about 2.6. After that, the LCOE start to increase due to the significant increase of the capital cost of the plant. This leads to the conclusion that solar multiple 3 is the most economical value which provide the minimum LCOE of the electricity produced at this design parameters of the plant.

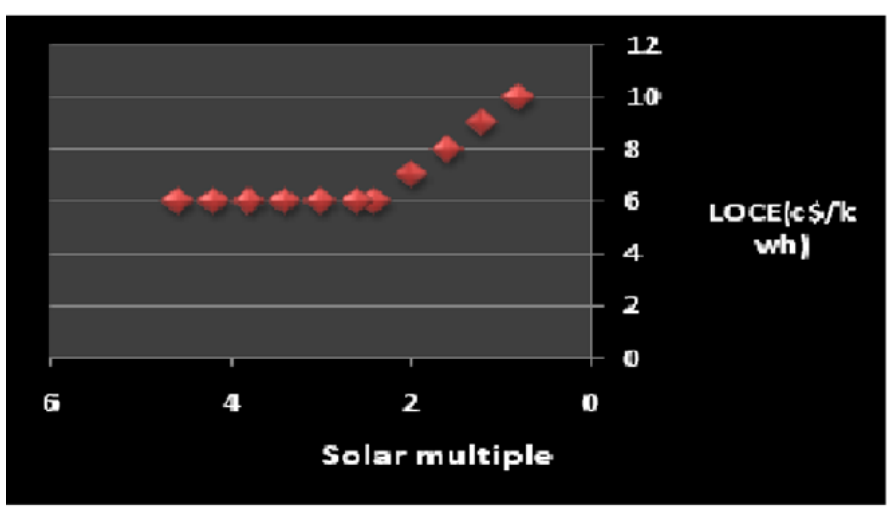

Figure 5: Effect of solar multiple on the LCOE

\section{ESTIMATION OF ENERGY OUTPUT}

This chart Figure 6 demonstrates the annual energy performance of the power plant. The annual net electrical energy produced is $70 \mathrm{GWh} /$ year with an overall annual efficiency of the plant is $35 \%$. It can be observed the main energy losses are occurred in the solar filed and the power block. The losses in the solar field are represented in optical losses in solar collectors and thermal losses due to different components such as receivers and pipe lines. In addition, power block losses are represented in mechanical, thermal and parasitic losses which are required to operate auxiliary equipment's.

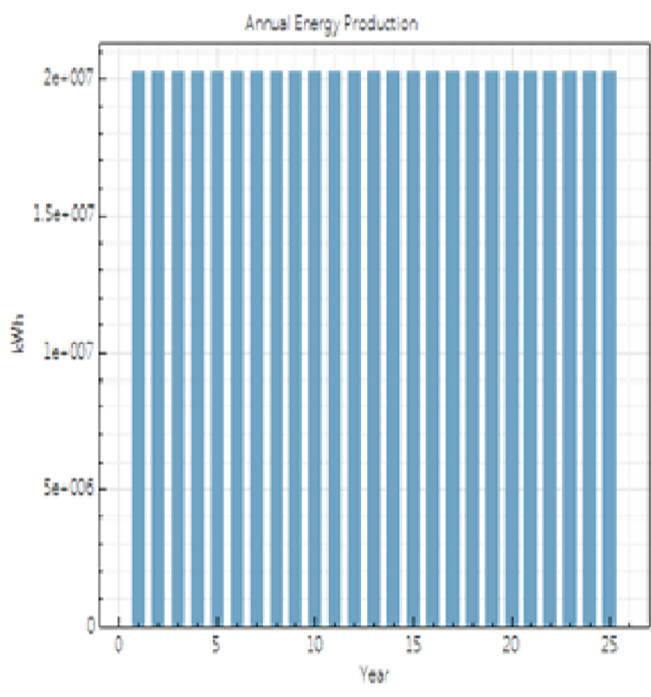

Figure 6: Annual energy flow of the proposed plant

\section{ECONOMIC}

The economic results of this project were studied on the basis of the electric power produced. The cost of energy use was calculated using the annual project direct costs, including solar collectors, receivers and heat Energy storage costs, as well as indirect project costs such as engineering and construction costs. The simulation results show that the actual cost of the proposed plan is $6 \mathrm{c} \$ / \mathrm{KW}$, and the contribution of each component of the plant in this total amount is illustrated in Table 7. more detail. It can be noted that the total half-cost of LCO contributes to solar energy with the storage capacity of the thermal energy at the same cost ratio at a rate of $50 \%$ of the cost of the plant.

\begin{tabular}{|c|c|}
\hline Component & $\mathrm{c} \$ / \mathrm{kWh}$ \\
\hline Solar field & 1.5960 \\
\hline Thermal storage & 0.9945 \\
\hline Indirect cost & 0.6632 \\
\hline HTF & 0.4734 \\
\hline Site improvement & 0.1774 \\
\hline
\end{tabular}

\section{CONCLUSIONS}

This paper presents a Parabolic trough modeling tool model SAM is able to predict the annual production and performance of every hour, and the economic return project. Main features of the model view and discussed along with a case study to demonstrate the function. Based on extensive review of previously developed models that work on the applicability of hybrid system and support conventional power plants, add solar system.

Proposed the establishment of a power plant with a capacity equivalent to $70 \mathrm{GW} /$ year taking into account the northern location of Libya. This energy from the solar will be saving fuel consumption, the fuel saving for energy $20 \mathrm{MW} / \mathrm{h}$ will be 5.24 tone $/ \mathrm{h}$, and the annual fuel saving will be $45.27 \mathrm{k}$ tone of oil. The avoided carbon dioxide emissions as a result of employing the System is $101.23 \mathrm{k}$ tone / year. This solar technology, which represents a type of solar technology, has shown good results and competitive prices to meet the demand for electric power to switch to investment in these types of solar technologies and reduce the consumption of conventional energy to reduce environmental pollution.

The potential of solar energy is affected by the specific tracking mode. The highest potential is the case when a surface at the viewing angle tilts with East and West tracking, this is appropriate for CSP technologies. The large problem with this technology is associated with the requirements of the surface area and associated initial cost. SAM can be used by the energy demand in Libya can be satisfied with the concentrated solar plant at $50 \%$ (storage system of 6 hours). The total cost and LCO are in accordance with the minimum stipulated.

\section{REFERENCES}

[1] Mohamed, A. Al-Habaibeh, H. 2013. An investigation into the current utilization and prospective of renewable energy resources and technologies in Libya. Renewable Energy, 50, 732-740.

[2] GCSPP. 2014. Global Concentrating Solar Power Potentials. http://www.dlr.de/tt/en/desktopdefault.aspx/tabid-2885/4422_read16596/. Accessed on June 20,

[3] Turchi, C.S., Ma, Z. 2011. National Renewable Energy Laboratory Michael Erbes Enginomix, LLC to be presented at the ASME Turbo Expo 2011 Vancouver, Canada. 6-10.

[4] Pacheco, J.E. 2002. Final Test and Evaluation Results from the Solar Two Project. SAND 2002 - 0120.

[5] Kelly, B.D., Herrmann, U., Kearney, D.W. 2000. Evaluation and performance modeling for integrated solar combined cycles systems and thermal storage system, Final report on contract RAR-9-29442-05. National Renewable Energy Laboratory, September.

[6] DLR. 2006a. Institute of Technical Thermodynamics and Section Systems Analysis and Technology Assessment, Trans-Mediterranean Interconnection for Concentrating Solar Power, Federal Ministry for the Environment; Nature Conservation and Nuclear Safety Germany, Stuttgart, Germany.

[7] Grena, R., Tarquini, P. 2011. Solar linear Fresnel collector using molten nitrates as heat transfer fluid. Energy, 36 (2), 1048-1056. 
[8] IDEAM. 2013. Atlasde Radiacín Solar en Colombia. Available: https://documentacion.ideam.gov.co/openbiblio/Bvirtual/019649/0196 49.htm

[9] Elsaket, G. 2007. Simulating the integrated solar combined cycle for power plants application in Libya [Master thesis]. School of Engineering, Cranfield University.

[10] Zarza, E., Valenzuela, L. 2004. Direct steam generation in parabolic troughs: Final results and conclusions of the DISS project. Energy, 29 (1), 635-644.

[11] Quaschning, V. 2003. Solar Thermal Power Plants. Renewable Energy World, 6, 109-113.

[12] Jones, J. 2007a. CSP lifts off. Nevada Solar One comes to life. Renewable Energy World, 10 (3), 36-42.

[13] Greenpeace International. 2003. Solar Thermal Power 2020 Exploiting the Heat from the Sun to Combat Climate Change, ISBN:9073361-82-6, Greenpeace and the European Solar Thermal Industry Association

[14] DLR. (2006b). Concentrating Solar Power for the Mediterranean Region, available at: http://www.dlr.de/tt/med-csp (accessed 11/11).

[15] Hosseini, R., Soltani, M., Valizadeh, G. 2005/8. Technical and economic assessment of the integrated solar combined cycle power plants in Iran", Renewable Energy, 30 (10), 1541-1555.
[16] Saleh, I. 2006. Prospects of Renewable Energy in Libya, Locarno Institute of Solar Research, Switzerland.

[17] GECOL. 2010. GECOL Annual Report 2010, General Electricity Company of Libya, Tripoli, Libya.

[18] Kaygusuz, K. 2011. Prospect of concentrating solar power in Turkey: The sustainable future, Renewable and Sustainable Energy Reviews, 15, 808-814.

[19] Blair, N., Dobos, A., Freeman, J., Neises, M. 2014. Wagner, System Advisor Model, SAM 2014.1.14: General Description, in, National Renewable Energy Laboratory (NREL).

[20] Belgasim, B., M., Elmnefi. 2014. Evaluation of a Solar Parabolic Trough Power Plant under Climate Conditions in Libya, SET2014-E10031.

[21] Solar Paces. 2005. Solar Parabolic Trough, Available at http://www.solarpaces.org/Library/library.

[22] SAM. 2010. System Advisor Model (SAM). 04-05. Available: https://sam.nrel.gov/

[23] BP. 2013. Statistical Review downloads BP Global. Available: http://www.bp.com/en/global/corporate/about-bp/statistical-reviewof-world-energy-2013/statistical-reviewdownloads.html. 